\title{
Contribution of cytosine desaminases of AID/APOBEC family to carcinogenesis
}

\author{
Irina Zotova ${ }^{1,2}$, Elena Stepchenkova ${ }^{1,2}$, and Youri Pavlov ${ }^{3,4}$ \\ ${ }^{1}$ Vavilov Institute of General Genetics Russian Academy of Sciences, Saint Petersburg Branch, \\ Universitetskaya nab., 7-9, Saint Petersburg, 199034, Russian Federation \\ ${ }^{2}$ Department of Genetics and Biotechnology, Faculty of Biology, \\ Saint Petersburg State University, Universitetskaya nab., 7-9, Saint Petersburg, 199034, \\ Russian Federation \\ ${ }^{3}$ Eppley Institute for Research in Cancer and Allied Diseases, \\ University of Nebraska Medical Center, Omaha, NE, 68198, USA \\ ${ }^{4}$ Departments of Microbiology and Pathology; Biochemistry and Molecular Biology; \\ Genetics, Cell Biology and Anatomy, University of Nebraska Medical Center, Omaha, \\ $\mathrm{NE}, 68198$, USA
}

Address correspondence and requests for materials to Irina Zotova, info@grayhawk.spb.ru, i.zotova@spbu.ru

\begin{abstract}
Cytosine deaminases of the AID/APOBEC family have a weighty influence on human health. These enzymes are part of the innate and humoral immunity; they participate in lipid metabolism and muscle development, protect cells from viruses and regulate retrotransposition. If the activity of AID/APOBEC deaminases is misregulated, they can become "weapons of mass destruction," causing deaminations in unprotected single-stranded DNA regions leading to genome-wide mutagenesis. Ultimately, mutations contribute to cell malignancy and rapid evolution of cancer cells, helping them to evade the organism's defense. Also, hypermutable tumor cells develop resistance to anti-cancer drugs. Here we overview current understanding of the structure, functions, and regulation of AID/APOBEC cytosine deaminases in connection to carcinogenesis.
\end{abstract}

Keywords: Cytosine deaminases AID/APOBEC, DNA damage, mutation, cancer.

Citation: Zotova, I., Stepchenkova, E., and Pavlov, Y. 2019. Contribution of cytosine desaminases of AID/APOBEC family to carcinogenesis. Bio. Comm. 64(2): 110-123. https://doi.org/10.21638/spbu03.2019.203

Author's information: Irina Zotova, Junior research fellow, orcid.org/0000-0001-63935645; Elena Stepchenkova, PhD, Head of Laboratory, orcid.org/0000-0002-5854-8701; Youri Pavlov, Dr. of Sci. in Biology, Professor, Head of Laboratory, orcid.org/0000-00031179-5796

Manuscript Editor: Anton Nizhnikov, Department of Genetics and Biotechnology, Faculty of Biology, Saint Petersburg State University, Saint Petersburg, Russia

Received: May 29, 2019;

Revised: June 3, 2019;

Accepted: July 13, 2019;

Copyright: @ 2019 Zotova et al. This is an open-access article distributed under the terms of the License Agreement with Saint Petersburg State University, which permits to the authors unrestricted distribution, and self-archiving free of charge.

Funding: Buffett Cancer Center Pilot Grant 07-2018 to YP; Assignment of Russian Federation Government № 0112-2019-0001 to ES.

Competing interests: The authors have declared that no competing interests exist.
Carcinogenesis is often associated with the accumulation of a large number of new mutations in somatic cells. In one scenario, driver mutations in proto-oncogenes or tumor suppressor genes trigger uncontrolled cell proliferation, which is often accompanied by a decrease in the accuracy of replication and repair (Loeb et al., 1974; Loeb, 2001). In another, the driver mutation can by itself cause a mutator phenotype that leads to mutations in oncogenes and onset of tumorigenesis. During tumor growth, its cells accumulate additional mutations, the number of which increases after each division. Some of these mutations enhance the tumor aggressiveness and cause drug resistance of tumor cells; others are called "passenger mutations" and do not affect carcinogenesis (Stratton et al., 2009; Martincorena et al., 2015; Martincorena et al., 2017; Bailey et al., 2018).

Different tumors can differ significantly by the quantity of accrued mutations, mutation types, and their distribution along the genome, which depends on the nature of mutagenic processes operating in the specific tumor. Therefore, analysis of mutational spectra can serve as a tool to deduce what was the cause of mutations in tumors (Rogozin et al., 2003; Alexandrov et al., 2013; Rogozin et al., 2018). Recently, cytosine deaminases of the AID/APOBEC family have been implicated in etiology in many types of tumors. Enzymes of the AID/APOBEC family regularly participate in various cellular processes, from RNA editing to innate and humoral immunity, by deaminating cytosine to uracil in DNA or RNA (Conticello, 2008). Genome-wide deamination would cause a genetic catastrophe. The 
activity of cytosine deaminases in the cell is strictly regulated and limited to a few mRNA molecules or selected genome loci. Aberrant regulation of deaminase activity leads to genome-wide deaminations causing catastrophic accumulation of mutations and cancer (Burns et al., 2013; Roberts and Gordenin, 2014; Rogozin et al., 2019).

\section{Introduction to deaminases of the AID/APOBEC family}

At the moment, 11 human enzymes of the AID/ APOBEC family are known. They have different tissuespecific roles. All of them contain a conservative zincdependent cytidine-deaminase catalytic domain (CDA) (Samaranayake et al., 2006; Conticello, 2008; Salter et al., 2016) (Fig. 1). Those enzymes of this family that possess enzymatic activity catalyze a simple biochemical reaction of cytosine to uracil deamination in the singlestranded RNA or DNA (Fig. 2). The appearance of uracil in either RNA or DNA alters the coding properties of the nucleic acid molecule, and mutations appear after replication (Fig. 3, upper right corner). Also, uracil in DNA is a substrate for base excision DNA repair. During repair, apyrimidinic (AP) sites and, further, singlestrand breaks/gaps can occur, which also have a mutagenic potential (Lada et al., 2007) (Fig. 3). Breaks during base excision repair are a prerequisite to the recombinogenic activity of deaminases (Di Noia and Neuberger, 2004; Poltoratsky et al., 2004). Closely spaced deaminations on opposite DNA strands may lead to doublestrand breaks (Fig. 3, lower right). The catalytic activity of some deaminases or deaminase modules, APOBEC2, APOBEC4, and N-terminal domain of both APOBEC3B and APOBEC3G is not known (Fig. 2).

APOBEC1 (apolipoprotein B mRNA Editing Catalytic subunit 1) was the first identified member of the AID/APOBEC enzyme family performing deamination of cytosine in nucleic acids. In 1993, APOBEC1 was shown to be the catalytic subunit of a protein-editing complex that post-transcriptionally edits apolipoprotein B mRNA (Chen et al., 1987; Powell et al., 1987). The complete form of this apolipoprotein containing 4536 amino acids (ApoB100) is synthesized in the liver and the small intestine cells. Deamination of cytosine to uracil in position 6666 of $A P O B$ mRNA leads to substitution of CAA glutamine codon to UAA stop codon. When modified mRNA carrying a premature stop codon is translated, a shortened version of APOB is synthesized with a size of $48 \%$ of the original form (ApoB48) (Teng et al., 1993; Davidson et al., 1995). Thus, in natural conditions, APOBEC1 preferably deaminates only one specific cytosine residue in the mRNA, though recently it was found that, in addition to apolipoprotein mRNA, APOBEC1 can edit 3'UTR regions of 32 different mRNAs (Rosenberg et al., 2011). It is possible, thereby for APOBEC1 to exert influence upon gene expression by microRNA and other ways. When heterologously expressed in bacteria and yeast, APOBEC1 can deaminate genomic DNA, inducing numerous substitutions in CG pairs (Harris et al., 2002; Lada et al., 2011a).

Deaminase AID (Activation-induced deaminase) initiates the somatic hypermutagenesis (SHM) and class-switch recombination of immunoglobulin genes (Muramatsu et al., 1999). During SHM, uracil in the DNA template of the variable IG regions leads to $\mathrm{C} \rightarrow$ $\mathrm{T}$ transitions when replicated (Fig. 3). Also, uracil-containing DNA may be repaired by the base excision repair (BER) pathway. When uracil-DNA glycosylase (UNG) cuts uracil out from DNA the intermediate product, transient AP-sites are formed. Unprocessed AP-sites block the major replicative DNA polymerases but could be bypassed in error-prone fashion by Y-family translesion DNA polymerases (Casali et al., 2006; Lada et al., 2007). In another pathway of SHM, U:G pairs are recognized by DNA mismatch repair (MMR), which generates gaps in the DNA duplex. In B cells, the gaps are oddly filled with the participation of inaccurate DNA polymerase $\eta$ (Fig. 3). As a result, numerous and various point mutations appear in the variable regions of the immunoglobulin genes of activated B-lymphocytes, increasing the diversity of the antibodies (Muramatsu et al., 2000; Yoshikawa et al., 2002; Papavasiliou and Schatz, 2002; Di Noia and Neuberger, 2007). Another factor of immunoglobulins diversity, class-switch recombination, also depends on AID. Uracils, appearing on the border of constant regions of immunoglobulin heavy chain genes, are excised by BER or MMR, resulting in singleand double-stranded breaks that induce recombination leading to antibody isotype switching from $\operatorname{IgM}$ to $\operatorname{IgG}$, IgA or IgE (Muramatsu et al., 2000; Revy et al., 2000; Okazaki et al., 2002; Stavnezer and Schrader, 2006; Di Noia and Neuberger, 2007).

After the discovery of the role of AID in immunity, it was unclear whether it deaminated either DNA or RNA (Muramatsu et al., 2000). Seminal experiments by Michael Neuberger's group unequivocally demonstrated that AID deaminates DNA (Petersen-Mahrt et al., 2002). The expression of the AID gene in E. coli cells was mutagenic, and the effect was much stronger in ung1 cells unable to excise uracil from DNA (Petersen-Mahrt et al., 2002; Beale et al., 2004). Purified AID deaminated single-stranded DNA in vitro, producing clustered mutations with a signature similar to mutations in immunoglobulin genes (Pham et al., 2003). Human deaminase AID expressed in yeast cells is mutagenic, too (Poltoratsky et al., 2004). AID increased the frequency of $\mathrm{Can}^{\mathrm{r}}$ forward mutations almost 8 -fold in the wild-type strain and 82 -fold in the ung1 mutant. The synergistic effect was observed for the frequency of reversions of nonsense mutation (that occur mainly by suppressor mutations in 


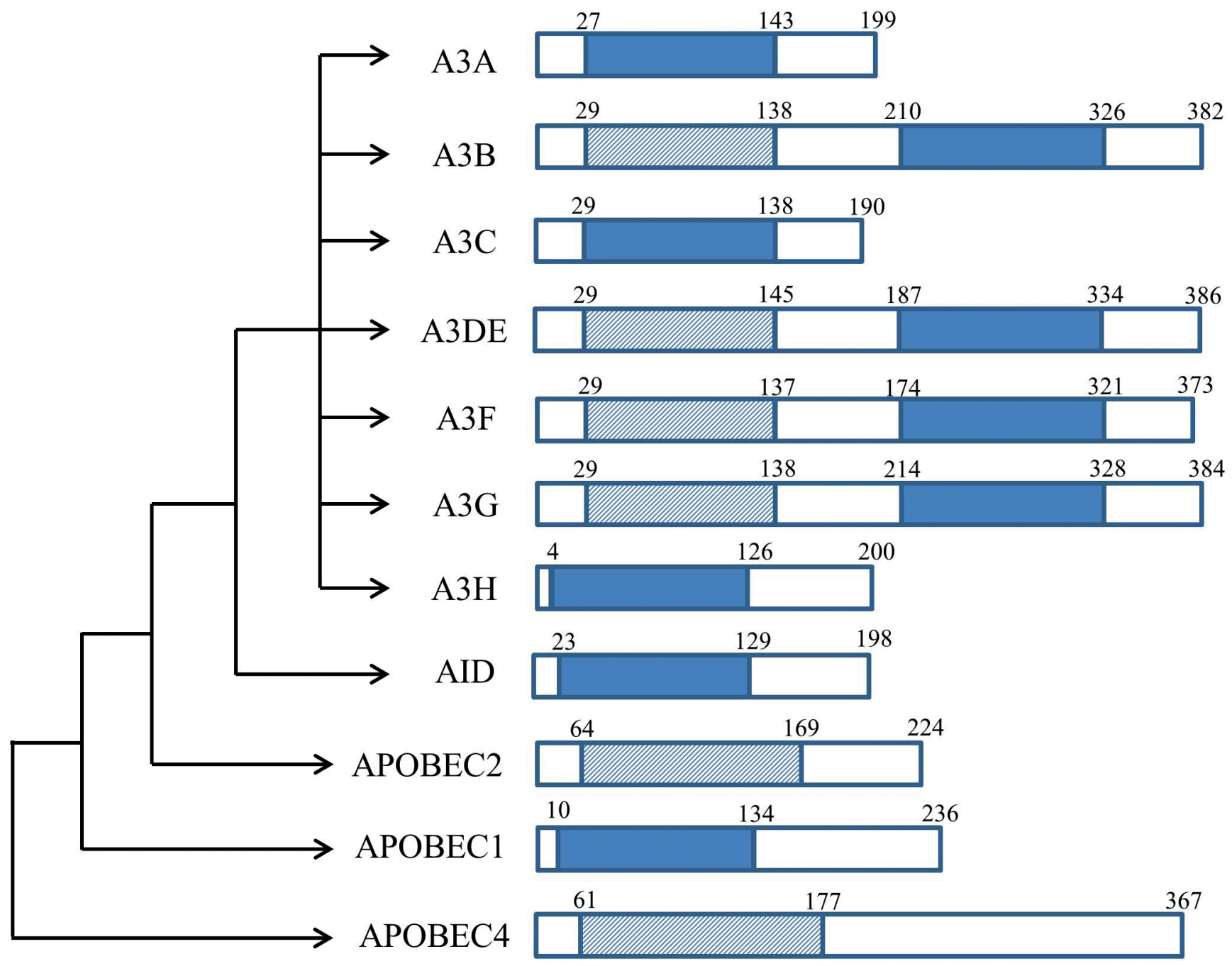

Fig. 1. Phylogenetic tree of human AID/APOBEC deaminases (Rogozin et al., 2007; Krishnan et al., 2018). Active deaminase modules are shown in solid blue, deaminase domains which have no catalytic activity are shown as cross-hatched bars. The numbers above each bar refer to amino acid positions according to (https://www.uniprot.org).

\section{Cytosine}

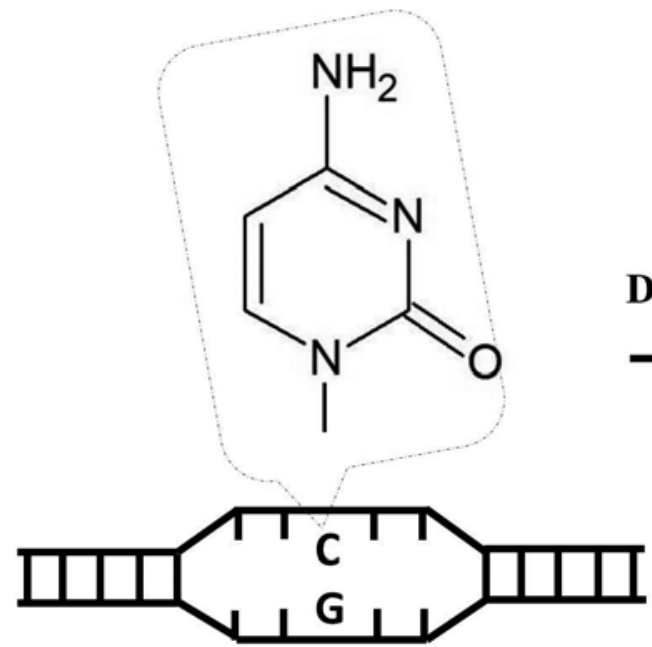

\section{Uracil}

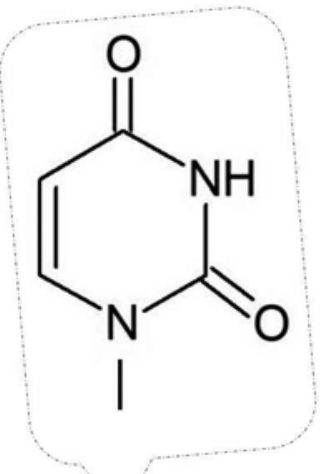

Deaminase AID/APOBEC

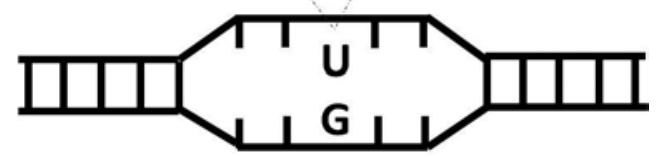

Fig. 2. Cytosine deamination performed by AID/APOBEC family deaminases on ssDNA generates U:G mispair. 


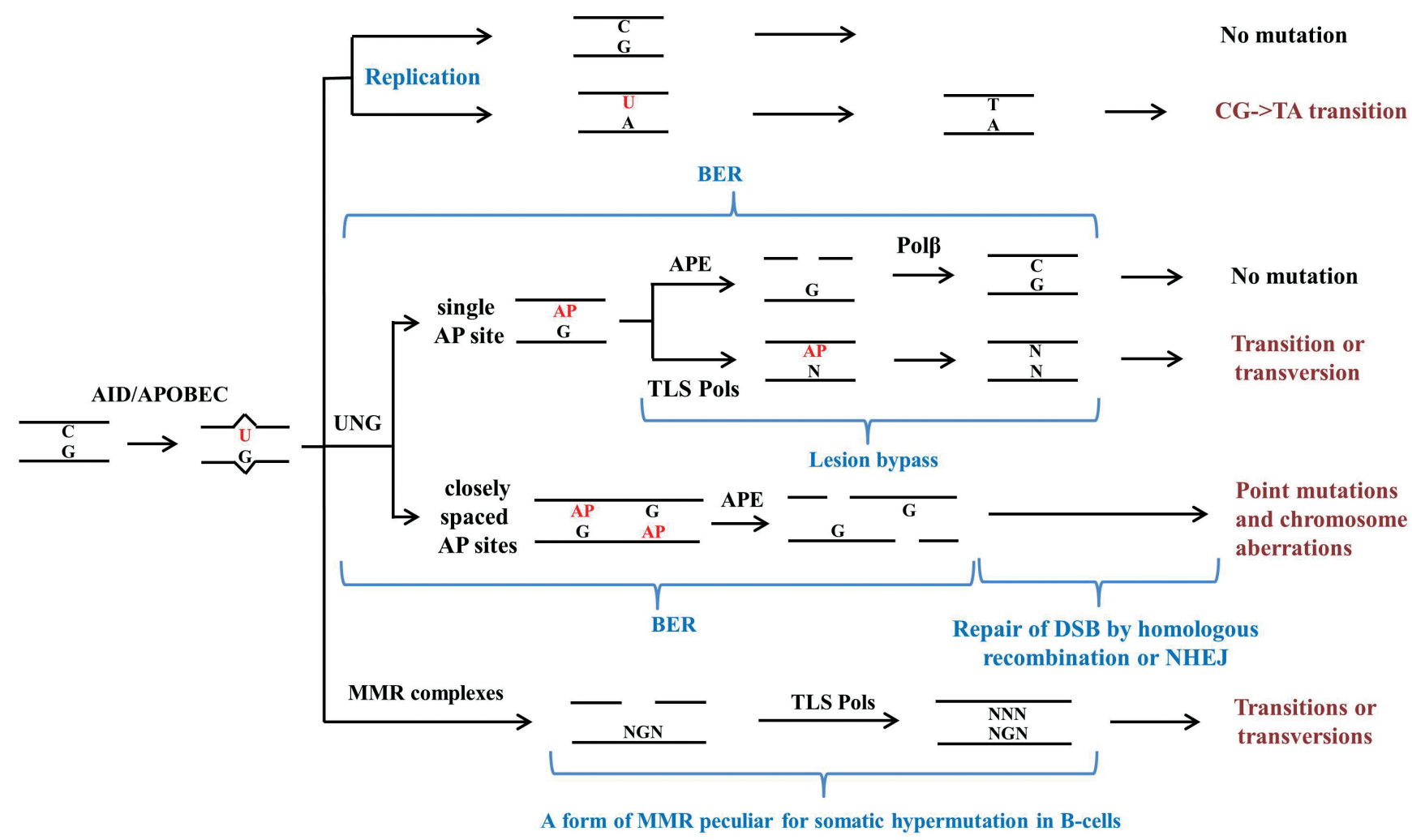

Fig. 3. Genetic consequences of cytosine deamination in DNA by AID/APOBEC. Altered DNA is shown in red; operating processes are shown in blue, enzymatic systems in black and resulting genetic alterations in maroon. $\mathrm{U}$ - uracil; AP - apyrimidinic site; $\mathrm{N}-$ any base; $\mathrm{BER}-$ base excision repair; MMR - mismatch repair; NHEJ — non-homologous end joining; UNG - uracil-DNA-glycosylase; APE - AP endonuclease; Pol $\beta$ - DNA polymerase $\beta$; TLS Pols - translesion DNA polymerases; DSB - double-strand DNA break.

the anticodons of tRNA genes) in the ung1 strain, with an increase up to 1290 -fold over the wild-type. Sequencing of the CAN1 gene in AID-induced Can ${ }^{\mathrm{r}}$ mutants revealed that most mutations were transitions in GC pairs in a context similar to SHM (Mayorov et al., 2005; Rogozin and Pavlov, 2006). Genome-wide studies detected mutational clusters with a predominance of $\mathrm{C} \rightarrow$ T transitions (Lada et al., 2012; Taylor et al., 2013).

APOBEC2 is found in the heart and skeletal muscles of mice, chickens, and humans (Liao et al., 1999; Li et al., 2014). It is necessary for the normal development of muscles and weight gain in mice (Sato et al., 2009). In the absence of APOBEC2, animals develop age-dependent myopathy (Sato et al., 2009), which was related to mitochondrial function defects (Sato et al., 2017). Heterologous expression of $A P O B E C 2$ in yeast and bacteria did not lead to a mutator phenotype (Lada et al., 2011a), and APOBEC2 does not deaminate DNA in vitro (Harris et al., 2002; Lada et al., 2011a).

The APOBEC3 (A3) human deaminase subfamily includes seven proteins: A3A, A3B, A3C, A3DE, $\mathrm{A} 3 \mathrm{~F}, \mathrm{~A} 3 \mathrm{G}$, and $\mathrm{A} 3 \mathrm{H}$, possessing one deaminase module $(\mathrm{A} 3 \mathrm{~A}, \mathrm{~A} 3 \mathrm{C}, \mathrm{A} 3 \mathrm{H})$ or two modules $(\mathrm{A} 3 \mathrm{~B}, \mathrm{~A} 3 \mathrm{DE}, \mathrm{A} 3 \mathrm{~F}$, A3G), (Fig. 1). The genes encoding these proteins are located on chromosome 22 in tandem (Jarmuz et al.,
2002). APOBEC3 deaminases protect cells from exogenous and endogenous retroelements by inducing hypermutagenesis in the viral genome. A3B, A3DE, A3F, A3G, and $\mathrm{A} 3 \mathrm{H}$ inhibit the replication and infectivity of HIV1 (Doehle et al., 2005; Chaipan et al., 2013). A3G has been shown to inhibit HIV-1/ $\Delta$ vif infectivity through the degradation or hypermutagenesis of the viral minusstrand DNA (Sheehy et al., 2002; Harris et al., 2003). $\mathrm{A} 3 \mathrm{~B}, \mathrm{~A} 3 \mathrm{~F}$, and $\mathrm{A} 3 \mathrm{G}$ prevent infection with the hepatitis $\mathrm{B}$ virus by introducing numerous CG $\rightarrow$ TA transitions into the virus DNA (Suspene et al., 2005; Bonvin et al., 2006). A3A, A3B, A3DE, and A3H inhibit the Alu retrotransposition (Bogerd et al., 2006; Orecchini et al., 2018). A3A, A3C, and A3H deaminate papillomavirus DNA (Vartanian et al., 2008). A3A inhibits replication of the adeno-associated virus (AAV), a member of the parvovirus family (Chen et al., 2006). A3A, which has one deaminase module, can inhibit replication of both wildtype AAV and the autonomous parvovirus minute virus of mice (MVM) by a DNA deamination-independent mechanism (Narvaiza et al., 2009). Perhaps deaminase binds to viral RNA and sterically inhibits further elongation of reverse transcription (Bishop et al., 2008). In this relation, APOBEC1, all APOBEC3 proteins and another member of this family, deaminase AID, inhibit hu- 
man LINE-1 retrotransposition, and can do it through a deamination-independent manner (Bogerd et al., 2006; Muckenfuss et al., 2006; Stenglein and Harris, 2006; Kinomoto et al., 2007; Schumann, 2007; Pak et al., 2011; Orecchini et al., 2018).

Although the single cytidine-deaminase domain of A3A has significant homology with the C-terminal domain of $\mathrm{A} 3 \mathrm{G}(\sim 65 \%)$ and $\mathrm{A} 3 \mathrm{~B}(\sim 90 \%)$, A3A has no antiviral activity against HIV-1 (Goila-Gaur et al., 2007; Caval et al., 2014). Endogenous A3A is a predominantly cytoplasmic protein and is not expected to be genotoxic (Land et al., 2013), but when upregulated, it causes DNA damage (Suspène et al., 2017). Under conditions of overexpression, A3A becomes genotoxic (Land et al., 2013) and can enter the nucleus (Chen et al., 2006). Studies have shown that A3A induction activates severe DNA damage response (DDR) in a deaminase-dependent manner. Ectopic expression of $\mathrm{A} 3 \mathrm{~A}$ in U2OS osteosarcoma cells caused an accumulation of phosphorylated histone $\gamma-\mathrm{H} 2 \mathrm{AX}$, which is a marker of double-stranded DNA breaks (Chowdhury et al., 2005; Landry et al., 2011). At the same time, phosphorylated forms of replication protein A (RPA), activation of ATM protein kinase, and cell cycle arrest in the early $S$ phase were observed in response to DNA damage (Shiloh, 2003; Jackson and Bartek, 2009; Landry et al., 2011). While a mutant A3A gene encoding a protein without deaminase activity was expressed, a cascade of events of the response to DNA damage was not triggered. In HEK293 cells, overexpression of A3A was also cytotoxic (Burns et al., 2013). Recently, it was shown that, besides DNA, A3A could deaminate transcripts of 3078 genes at more than 4200 sites and change the amino acid sequence of 1110 proteins (Sharma et al., 2015; Sharma et al., 2017). Those include genes associated with breast cancer, hematologic neoplasms, amyotrophic lateral sclerosis, Alzheimer disease, and primary pulmonary hypertension (Sharma et al., 2017). A3A expression is mutagenic in yeast cells (Taylor et al., 2013; Hoopes et al., 2016). Heterologous expression of the two-domain A3B is also mutagenic in E. coli and yeast (Bogerd et al., 2006; Taylor et al., 2013). The N-terminal deaminase module of $\mathrm{A} 3 \mathrm{~B}$ does not possess the catalytic activity and is not mutagenic, but enhances both the deaminase activity of the C-terminal domain and binding to the substrate single-stranded DNA (Bogerd et al., 2006; Fu et al., 2015). Heterologous expression of $\mathrm{A} 3 \mathrm{C}$ and $\mathrm{A} 3 \mathrm{G}$ is mutagenic in E. coli and yeast (Harris et al., 2002; Schumacher et al., 2005; Lada et al., 2011a; Taylor et al., 2013).

APOBEC4 deaminase was found bioinformatically by analyzing protein sequence databases and is present in mammals, chickens, and frogs (Rogozin et al., 2005). It weakly interacts with single-stranded DNA, does not exhibit deaminase activity in vitro, and enhances the replication of HIV-1 (Marino et al., 2016). No mutator phenotypes were detected in yeast and bacteria expressing APOBEC4 (Lada et al., 2011a).

\section{Deamination and mutagenesis by AID/APOBECS}

All currently known human AID/APOBECs are structurally similar to each other, but their functions are very different. After the breakthrough discovery of deaminases, especially AID, the urgent problem was to understand how they realize their catalytic potential in targeted genome compartments, in specific cells and tissues. Purified AID needs RNase treatment to exert deamination activity on single-stranded DNA (Bransteitter et al., 2003); RNA attenuates A3B activity (Xiao et al., 2017), suggesting a role of RNA bound to deaminases in the regulation of their activity. AID deaminations in singlestranded DNA in vitro lead to clustered mutations in defined DNA sequence contexts (Pham et al., 2003) by intertwined scanning and catalysis (Mak et al., 2013). Transcription has an essential role in AID activity because it constantly generates ssDNA (Pham et al., 2003). AID causes multiple clustered mutations under transcriptional pausing and stalling (Canugovi et al., 2009). Transcription is not the only source of unprotected ssDNA, and mutations attributed to APOBECs are detected in parity on both transcribed and non-transcribed DNA strands in human tumors (Kazanov et al., 2015). Yeast cells expressing human AID have revealed deamination on both DNA strands with more efficient uracil repair in the transcribed DNA strand (Mayorov et al., 2005). Genome-wide studies of APOBEC-induced mutations in yeast firmly established the connection of deamination with transcription (Taylor et al., 2014; Lada et al., 2015; Saini et al., 2017). DNA may be transiently exposed to APOBEC deaminases during replication (Green et al., 2016). Lagging DNA strand replication involves more complicated transactions, thus leaving unprotected ssDNA more frequently. Not surprisingly, a third of mutations attributed to APOBECs are inferred to occur during DNA replication on the lagging strand in cancer cells (Seplyarskiy et al., 2016). APOBEC-dependent deamination preferentially occurs in the lagging strand in yeast (Hoopes et al., 2016) and E. coli (Bhagwat et al., 2016). One additional source of ssDNA substrates for deaminases is homologous recombination (Poltoratsky et al., 2010; Taylor et al., 2013).

Double-stranded DNA is resistant to deaminase action. Transcription, replication, and repair provide transient single-stranded regions that can be deaminated. Single-strand DNA binding proteins (e.g., RPA) attenuate the ability of APOBECs to work on ssDNA (Pham et al., 2008; Lada et al., 2011b). Accessibility of ssDNA to RPA versus competing APOBECs determines the extent of mutagenic action of deaminases. The sites/situations 
where the balance is shifted to APOBECs are one of the factors for the appearance of hypermutated regions in cells. The mutations caused by deaminases are found in the regions of the chromosomes that contain a large number of genes and are transcribed early (Kazanov et al., 2015).

\section{Footprints of deaminases in DNA}

Studies in microbial models and analysis of cancer genomes allowed identification of specific deaminase imprints in DNA termed "AID/APOBEC mutational signatures." A mutational signature is a specific combination of base substitutions and other mutations in a defined sequence context (Rogozin and Pavlov, 2003). By studying the mutational signatures in cancer cells, it is possible to deduce with some probability the strength and duration of the action of the mutagenic factor (Nik-Zainal et al., 2012). About 30 signatures of various mutational processes have now been identified in cancer genomes, two of them (no. 2 and no. 13) belong to the APOBEC family deaminases, (Nik-Zainal et al., 2012; Alexandrov et al., 2013; Alexandrov and Stratton, 2014). APOBEC mutational signatures were found in more than half of human cancers (Alexandrov et al., 2013). The remnants of APOBECs deaminations, $\mathrm{C} \rightarrow \mathrm{T}$ transitions and $\mathrm{C} \rightarrow$ $\mathrm{G}$ transversions in the preferred 5'-TC (A/T)-3' motifs that can be caused by $\mathrm{A} 3 \mathrm{~A}$ and $\mathrm{A} 3 \mathrm{~B}$, were found in $3.8 \%$ of multiple myeloma cases, along with translocations occurring in the vicinity of the preferred AID 5'-WRC-3' motifs. Patients with an increased number of such mutations had a poor prognosis (Walker et al., 2015).

The study of 1020 cell lines of various types of cancer from the COSMIC (Catalog of Somatic Mutations in Cancer) somatic mutation database has revealed APOBEC mutational signatures in more than 100 cell lines (Jarvis et al., 2018). In 5\% of skin cancer cell lines, $19 \%$ of lung cancer, and $48 \%$ of breast cancer, mutations were found that might have been induced by APOBEC deaminases. There was a strong positive correlation between the abundance of APOBEC signatures in breast cancer cell lines with overall base substitution mutation loads (Jarvis et al., 2018). Bladder cancer analysis by TCGA (The Cancer Genome Atlas) revealed the APOBEC mutational signature in $84 \%$ of bladder cancer samples. The expression of both A3A and A3B in bladder cancer samples correlated with overall mutation load in bladder cancer (Glaser et al, 2018). Mutations in the DNA damage response genes (TP53, ATR, BRCA2) and chromatin regulatory genes (ARID1A, MLL, MLL3) were substantially enriched in the bladder cancer samples with the APOBEC signature (Glaser et al., 2018).

In 2012, another interesting hallmark of deaminase action was discovered by the international team of researchers of the Wellcome Trust Sanger Institute in the analysis of the genomes of breast cancer samples. Among multiple scattered mutations, clusters of closely spaced mutations were found. The phenomenon was named kataegis, from Greek "thunderstorm." The majority of mutations were CG $\rightarrow$ TA transitions; therefore it was suggested that APOBEC deaminases are connected to kataegis (Nik-Zainal et al., 2012). Almost at the same time, C- or G-coordinated mutation clusters (multiple changes of either "C" or " $G$ " in continuous DNA strand) were detected in genomes of multiple myeloma, prostate, and head and neck cancer (Roberts et al., 2012) and were linked to APOBEC activity, because of frequently occurring mutations in TCW (W=A or T) motifs characteristic to several APOBEC deaminases (Roberts et al., 2012). Expression of model deaminase genes $P m C D A 1$ and AID in yeast resulted in kataegis, too, confirming a link between the activity of deaminases and kataegis (Lada et al., 2012; Lada et al., 2013). A3A and A3B mutation specificity in yeast was similar to mutations found in some breast cancers; kataegistic clusters depended on DSBs (Taylor et al., 2013). Kataegis is defined as the proximity of six or more mutations with an average intermutation distance less than one $\mathrm{kb}$ in the same DNA strand (Nik-Zainal and Morganella, 2017). Mechanistically, kataegis might be explained by the appearance of continuous single-stranded regions during transcription or repair of double-stranded DNA breaks or break-induced replication (Sakofsky et al., 2014). Kataegis is often observed in junction regions of chromosomal rearrangements in human tumor cells. Typically, the APOBEC signature consists of $\mathrm{C} \rightarrow \mathrm{T}$ transitions in the characteristic motifs and $\mathrm{C} \rightarrow \mathrm{G}$ transversions, which result from the operation of translesion polymerases on the damaged strand with an AP site (Taylor et al., 2013; Hoopes et al., 2017). The similarity in specificity and distribution of mutations induced by deaminases in model systems and found in tumors indicate that AID/APOBEC deaminases play a significant role in cancer origin and development.

\section{The role of AID/APOBECs in the etiology of cancer}

Discovery of deaminases led to a prediction that lack of control over deaminases in the cell might lead to genome-wide mutagenesis and cancer (Neuberger et al., 2003). The hypothesis quickly found experimental support from studies with model systems discussed above and evidence from analysis of human cancers; this led to the tremendous expansion of a number of publications on the roles of various deaminases in carcinogenesis (Rogozin et al., 2018).

Hepatic dysplasia and hepatocellular carcinoma were observed in transgenic mice and rabbits with constitutive expression of APOBEC1 (Yamanaka et al., 1995). With the constitutive expression of APOBEC2 in transgenic 
mice, liver and lung cancer developed, and changes in the RNA nucleotide sequence of some oncogenes were also found (Okuyama et al., 2011). Transgenic mice with constitutive expression of AID developed malignant T-cell lymphomas, and micro-adenomas/adenocarcinomas in the lung, hepatocellular carcinomas, gastric cancer; in parallel, point mutations in T-cell receptors, $M Y C$, KRAS, TP53 genes were frequently observed (Okazaki et al., 2003; Morisawa et al., 2008). Aberrant activity of AID can trigger double-stranded DNA breaks not only in immunoglobulin genes but in other susceptible genomic regions, which leads to chromosomal translocations between immunoglobulin genes and other genes. During such events, proto-oncogenes translocate to cis-regulatory transcriptional elements and strong immunoglobulin enhancers that cause unregulated constitutive expression of the translocated gene (Ramiro et al., 2004; Robbiani et al., 2009; Nussenzweig and Nussenzweig, 2010). Such rearrangements are the hallmark of lymphomas (Okazaki et al., 2007). AID is implicated in the hypermutagenesis of oncogenes controlling proliferation and apoptosisMYC, PIM1, JUND, and BCL2-and B cell development and activation genes-PAX5, CD79b, AICDA, IRF8, $B A C H 2$, and $N F K B$ - as well as promoters and super-enhancers regulating the cell cycle and apoptosis (Gaidano et al., 1997; Qian et al., 2014). Studies have shown that there are over a hundred of such genes (Casellas et al., 2016). Normally, AID activity is restricted to the activated B-lymphocytes and some tissues, but in most lymphomas, the expression of this deaminase is constant (Okazaki et al., 2007).

Analysis of the expression level of various deaminases in breast cancer has revealed that $38-70 \%$ of tissue samples and cell lines have an increase in the expression of APOBEC3B, but not other deaminases of this family. These cell lines have twice as many mutations as those that express low levels of $\mathrm{A} 3 \mathrm{~B}$ expression and an increase of $\mathrm{C} \rightarrow \mathrm{T}$ transitions. Knockdown of A3B caused a decrease in the total number of transitions (Burns et al., 2013). Therefore, it was concluded that A3B is the leading source of mutations in breast cancer. Further studies of 19 types of cancer according to The Cancer Genome Atlas (TCGA) revealed an elevated A3B level in head and neck, bladder, cervix, and lung cancers, also with $\mathrm{C} \rightarrow \mathrm{T}$ predominance in the context of 5'-TC-3', which is characteristic of APOBEC3 deaminases (Burns et al., 2013). In some types of cancer, these mutations reached $68 \%$ of all mutations (Roberts et al., 2013). In the case of estrogen-positive breast cancer, expression of A3B is associated with poor prognosis during treatment. A3B regulates the estrogen receptor, enhances tumor growth and confers resistance to treatment with tamoxifen (Periyasamy et al., 2015; Law et al., 2016).

Some experimental evidence, however, argues against the overwhelming dominance of $\mathrm{A} 3 \mathrm{~B}$ in cancer etiology. It turned out the human genome has the common deletion polymorphism on chromosome 22 in the APOBEC 3 subfamily gene locus (Kidd et al., 2007). Carriers of the deletion allele lack a $29.5 \mathrm{~kb}$ fragment between the fifth exon of $\mathrm{A} 3 \mathrm{~A}$ and the eighth exon of $\mathrm{A} 3 \mathrm{~B}$, and cells produce a transcript containing the 3 '-untranslated region (3'-UTR) from $\mathrm{A} 3 \mathrm{~B}$ and the coding part identical to the $\mathrm{A} 3 \mathrm{~A}$ gene. The main difference between the 3'-UTR of the two genes is that the A3A 3'-UTR contains Alu-repeat (Kidd et al., 2007). The deletion is rare in Europe (9\%) and Africa (0.9\%), more common in Asia (36.9\%) and America (57.7\%), and almost ubiquitous in Oceania (92.9\%) (Kidd et al., 2007). Contrary to the expectations, breast cancer rates are comparable in all these regions. Also, the polymorphism is more common in European and Chinese women with breast cancer, than in healthy ones (Xuan et al., 2013). The total number of mutations in the genomes of breast cancer cells is increased in cells with deletion polymorphism (Nik-Zainal et al., 2014). The A3A-UTR ${ }_{\mathrm{A} 3 \mathrm{~B}}$ chimeric transcript expressed in HEK293T cells increases both the chimeric A3A mRNA level yielding 10-20-fold and the deaminase activity $\mathrm{A} 3 \mathrm{~A}$ in comparison to $\mathrm{A} 3 \mathrm{~A}-\mathrm{UTR}_{\mathrm{A} 3 \mathrm{~A}}$. Therefore, it was concluded that the expression level of $\mathrm{A} 3 \mathrm{~A}$ is regulated by the $3^{\prime}$-UTR region. The chimeric protein also caused more damage and double-stranded breaks than the naturally occurring $\mathrm{A} 3 \mathrm{~A}$, which explained the association of deletion polymorphism with a large number of mutations in cancer cells (Caval et al., 2014). It became apparent that $A 3 B$ is not the only factor in mutagenesis conferred by deaminases in cancer.

APOBEC3A can be more cytotoxic and genotoxic than APOBEC3B (Caval et al., 2015). In yeast cells, it was possible to establish a difference in the preferred deamination motifs, YTCA for A3A and RTCA for A3B (Y = pyrimidine, $R$ = purine), and thereby determine what proportion of tumors possess $\mathrm{A} 3 \mathrm{~A}$ versus $\mathrm{A} 3 \mathrm{~B}$ signatures (Chan and Gordenin, 2015). It is uniformly agreed that $\mathrm{A} 3 \mathrm{~A}$ overexpression can cause double-stranded DNA breaks and apoptosis, but there is controversy in the case of A3B (Landry et al., 2011; Burns et al., 2013; Taylor et al., 2013; Caval et al., 2014). The study of the relative roles of $\mathrm{A} 3 \mathrm{~A}$ and $\mathrm{A} 3 \mathrm{~B}$ in cancer needs further thorough investigation.

\section{Factors affecting the activity of AID/APOBEC deaminases}

The normal expression of AID/APOBECs is tissue-specific in humans (Conticello, 2008; Salter et al., 2016). We know that the heterologous expression of deaminase genes in bacterial and yeast cells leads to an increase in the frequency of mutations (Harris et al., 2002; Lada et al., 2011a). High levels of deaminases are potentially harmful, though the correlation between deaminase lev- 
els and actual deamination is complicated (Siriwardena et al., 2018) and the activity of deaminases in human cells is under tight control. When the deaminase activity regulation is compromised, the enzymes deaminate cytosine in nonspecific loci of the genome, which leads to an increase in the frequency of mutagenesis and malignant transformation of tissues (Yoshikawa et al., 2002; Ramiro et al., 2004; Robbiani et al., 2009; Roberts et al., 2013). The search for factors affecting deaminase activity might help identify new risk factors and methods for the prevention and treatment of cancer.

Both bacterial lipopolysaccharides and human papillomavirus-like particles induce AID expression in murine B cells (Okazaki et al., 2007). Epstein-Barr virus and hepatitis $\mathrm{C}$ virus induce AID expression in B-lineage cells (Okazaki et al., 2007). Chronic inflammation on the background of cancer or virus infection leads to the release of cytokines TGF $\beta$, TNFa, IL-4, IL-13, which initiate the expression of $A I D$ and cause the subsequent mutation of the tumor suppressor TP53 and other genes and solid tumor development (Kumar et al., 2014; Choudhary et al., 2017). Studies show that in chronic inflammation and hypoxia, the risk of developing cancer is increased due to an elevated level of A3A and the subsequent enhancement of RNA editing by this protein, since the expression of $\mathrm{A} 3 \mathrm{~A}$ and $\mathrm{A} 3 \mathrm{~B}$ is stimulated by interferons (Bonvin et al., 2006; Sharma et al., 2017). Increasing the amount of these proteins is one of the stages in the development of the immune response to infection with viruses. Infection of breast and bladder cancer cell lines with Sendai virus led to a strong induction of $\mathrm{A} 3 \mathrm{~A}$, but more moderate induction of $\mathrm{A} 3 \mathrm{~B}$, possibly because of the initially high expression of A3B deaminase in cancer cells (Middlebrooks et al., 2016).

Cancer cells multiply faster than normal with fervent replication. Therefore, the number of mutations in tumors increases with time (Hanahan and Weinberg, 2011). Permanent divisions deplete protein complexes that ensure the stable progression of the replication fork. Many oncogenes induce replication stress, defined as the impediment of replication, which also contributes to the accumulation of mutations. The number of sites with unprotected ssDNA increases, creating favorable conditions for APOBEC mutagenesis (Cescon and HaibeKains, 2016; Hoopes et al., 2016). Anti-cancer drugs camptothecin, gemcitabine, hydroxyurea, and the DNA polymerase inhibitor $\alpha$-aphidicolin also induce replication stress. The stress increases the activity of deaminases A3A and A3B (Kanu et al., 2016).

It has been suggested that the regulation of the expression of $\mathrm{A} 3 \mathrm{~A}$ and $\mathrm{A} 3 \mathrm{~B}$ may also occur at the posttranscriptional level using miRNA. The $3^{\prime}$-UTR A3A is $674 \mathrm{bp}$ long. Hundreds of potential microRNA binding sites were found in the 3'-UTR of A3A.In the 3'-UTR of $\mathrm{A} 3 \mathrm{~B}$ with a length of $356 \mathrm{bp} 82$ potential microRNA binding sites were predicted. It is possible that the repression of $\mathrm{A} 3 \mathrm{~A}$ by miRNA will be tighter than $\mathrm{A} 3 \mathrm{~B}$ or chimeric $\mathrm{A} 3 \mathrm{~A}-\mathrm{UTR}_{\mathrm{A} 3 \mathrm{~B}}$ (Cao and Wu, 2017). Also, four kinds of miRNA bind to target sites in the AID 3'-UTR and reduce the amount of the protein (Zan and Casali, 2013). Modulation of APOBEC gene expression by miRNA might be a perspective method of modulation of deaminase activity in cancer.

There is no doubt that deaminases of the AID/ APOBEC family contribute significantly to tumor origins and progression. We expect that many puzzles and mysteries related to cancer/deaminases connection that surfaced during the first two decades of research in the field will be subject to intense future studies.

\section{References}

Alexandrov, L. B., Nik-Zainal, S., Wedge, D. C., Aparicio, S. A., Behjati, S., Biankin, A. V., Bignell, G. R., Bolli, N., Borg, A., Borresen-Dale, A. L., et al. 2013. Signatures of mutational processes in human cancer. Nature 500(7463):415-421. https://doi.org/10.1038/nature12477

Alexandrov, L. B. and Stratton, M. R. 2014. Mutational signatures: the patterns of somatic mutations hidden in cancer genomes. Current Opinion in Genetics \& Development 24:52-60. https://doi.org/10.1016/j.gde.2013.11.014

An, P., Johnson, R., Phair, J., Kirk, G. D., Yu, X., Donfield, S., Buchbinder, S., Goedert, J. J., and Winkler, C. A. 2009. APOBEC3B deletion and risk of HIV-1 acquisition. The Journal of Infectious Diseases 200(7):1054-1058. https://doi. org/10.1086/605644

Bailey, M. H., Tokheim, C., Porta-Pardo, E., Sengupta, S., Bertrand, D., Weerasinghe, A., Colaprico, A., Wendl, M. C., Kim, J., Reardon, B., et al. 2018. Comprehensive characterization of cancer driver genes and mutations. Cell 173(2):371-385.e318. https://doi.org/10.1016/j. cell.2018.02.060

Beale, R. C., Petersen-Mahrt, S. K., Watt, I. N., Harris, R. S. Rada, C., and Neuberger, M. S. 2004. Comparison of the differential context-dependence of DNA deamination by APOBEC enzymes: correlation with mutation spectra in vivo. Journal of Molecular Biology 337(3):585-596. https:// doi.org/10.1016/j.jmb.2004.01.046

Bhagwat, A. S., Hao, W., Townes, J.P., Lee, H., Tang, H., and Foster, P. L. 2016. Strand-biased cytosine deamination at the replication fork causes cytosine to thymine mutations in Escherichia coli. Proceedings of the National Academy of Sciences of the USA 113(8):2176-2181. https://doi. org/10.1073/pnas.1522325113

Bishop, K. N., Verma, M., Kim, E., Wolinsky, S. M., and Malim, M. H. 2008. APOBEC3G inhibits elongation of HIV-1 reverse transcripts. PLoS Pathogens 4(12):e1000231. https://doi.org/10.1371/journal.ppat.1000231

Bogerd, H. P., Wiegand, H. L., Hulme, A. E., Garcia-Perez, J. L., O'Shea, K. S., Moran, J. V., and Cullen, B. R. 2006. Cellular inhibitors of long interspersed element 1 and Alu retrotransposition. Proceedings of the National Academy of Sciences of the USA 103(23):8780-8785. https://doi. org/10.1073/pnas.0603313103

Bonvin, M., Achermann, F., Greeve, I., Stroka, D., Keogh, A., Inderbitzin, D., Candinas, D., Sommer, P., Wain-Hobson, S., Vartanian, J.-P., and Greeve, J. 2006. Interferon-inducible expression of APOBEC3 editing enzymes in human hepatocytes and inhibition of hepatitis $B$ virus replica- 
tion. Hepatology 43(6):1364-74. https://doi.org/10.1002/ hep.21187

Bransteitter, R., Pham, P., Scharff, M. D., and Goodman, M. F. 2003. Activation-induced cytidine deaminase deaminates deoxycytidine on single-stranded DNA but requires the action of RNAse. Proceedings of the National Academy of Sciences of the USA 100(7):4102-4107. https:// doi.org/10.1073/pnas.0730835100

Burns, M.B., Lackey, L., Carpenter, M. A., Rathore, A., Land, A. M., Leonard, B., Refsland, E. W., Kotandeniya, D., Tretyakova, N., Nikas, J. B., Yee, D., Temiz, N. A., Donohue, D. E., McDougle, R. M., Brown, W. L., Law, E. K., and Harris, R. S. 2013. APOBEC3B is an enzymatic source of mutation in breast cancer. Nature 494(7437):366-370. https://doi.org/10.1038/nature11881

Burns, M. B., Temiz, N. A., and Harris, R. S. 2013. Evidence for APOBEC3B mutagenesis in multiple human cancers. Nature Genetics 45(9):977-983. https://doi.org/10.1038/ ng.2701

Canugovi, C., Samaranayake, M., and Bhagwat, A. S. 2009. Transcriptional pausing and stalling causes multiple clustered mutations by human activation-induced deaminase. The FASEB Journal 23(1):34-44. https://doi. org/10.1096/fj.08-115352

Cao, W. and Wu, W. 2017. Apolipoprotein B mRNA Editing Enzyme, Catalytic Polypeptide-Like Gene Expression, RNA Editing, and MicroRNAs Regulation. MicroRNA and Cancer. Methods in Molecular Biology, vol. 1699. Humana Press, New York, NY. https://doi.org/10.1007/978-14939-7435-1_5

Casali, P., Pal, Z., Xu, Z., and Zan, H. 2006. DNA repair in antibody somatic hypermutation. Trends in Immunology 27(7):313-21. https://doi.org/10.1016/j.it.2006.05.001

Casellas, R., Basu, U., Yewdell W.T., Chaudhuri, J., Robbiani, D., and Di Noia, J. M. 2016. Mutations, kataegis and translocations in B cells: understanding AID promiscuous activity. Nature Reviews Immunology 16(3):164-176. https://doi.org/10.1038/nri.2016.2

Caval, V., Bouzidi, M. S., Suspène, R., Laude, H., Dumargne, M., Bashamboo, A., Krey, T., Vartanian, J., and Wain-Hobson, S. 2015. Molecular basis of the attenuated phenotype of human APOBEC3B DNA mutator enzyme. Nucleic Acids Research 43(19):9340-9. https://doi.org/10.1093/nar/gkv935

Caval, V., Suspene, R., Shapira, M., Vartanian, J., and WainHobson, S. 2014. A prevalent cancer susceptibility APOBEC3A hybrid allele bearing APOBEC3B 3'UTR enhances chromosomal DNA damage. Nature Communications 5:5129. https://doi.org/10.1038/ncomms6129

Cescon, D.W. and Haibe-Kains, B. 2016. DNA replication stress: a source of APOBEC3B expression in breast cancer. Genome Biology 17:202. https://doi.org/10.1186/ s13059-016-1069-y

Chaipan, C., Smith, J. L., Hu, W., and Pathak, V. 2013. APOBEC3G restricts HIV-1 to a greater extent than APOBEC3F and APOBEC3DE in human primary CD4 T cells and macrophages. Journal of Virology 87(1):444-453. https://doi. org/10.1128/JVI. 00676-12

Chan, K. and Gordenin, D. A. 2015. Clusters of multiple mutations: incidence and molecular mechanisms. Annual Review of Genetics 49:243-267. https://doi.org/10.1146/ annurev-genet-112414-054714

Chan, K., Roberts, S. A., Klimczak, L. J., Sterling, J. F., Saini, N., Malc, E. P., Kim, J., Kwiatkowski, D. J., Fargo, D. C., Mieczkowski, P.A., Getz, G., and Gordenin, D.A. 2015. An APOBEC3A hypermutation signature is distinguishable from the signature of background mutagenesis by APOBEC3B in human cancers. Nature Genetics 47(9):1067-72. https://doi.org/10.1038/ng.3378
Chen, H., Lilley, C. E., Yu, Q., Lee, D. V., Chou, J., Narvaiza, I., Landau, N. R., and Weitzman, M. D. 2006. APOBEC3A is a potent inhibitor of adeno-associated virus and retrotransposons. Current Biology 16(5):480-485. https:// doi.org/10.1016/j.cub.2006.01.031

Chen, S.H., Habib, G., Yang, C.Y., Gu, Z.W., Lee, B.R., Weng, S. A., Silberman, S. R., Cai, S. J., Deslypere, J. P., and Rosseneu, M. 1987. Apolipoprotein B-48 is the product of a messenger RNA with an organ- specific in-frame stop codon. Science 238(4825):363-366. https://doi. org/10.1126/science.3659919

Choudhary, M., Tamrakar, A., Singh, A. K., Jain, M., Jaiswal, A., and Kodgire, P. 2017. AID Biology: a pathological and clinical perspective. International Reviews of Immunology 37(1):1-20. https://doi.org/10.1080/08830185.2017.136 9980

Chowdhury, D., Keogh, M-C., Ishii, H., Peterson, C. L., Buratowski, S., and Lieberman, J. 2005. y-H2AX dephosphorylation by protein phosphatase $2 \mathrm{~A}$ facilitates DNA double-strand break repair. Molecular Cell 20(5):801-809. https://doi.org/10.1016/j.molcel.2005.10.003

Conticello, S.G. 2008. The AID/APOBEC family of nucleic acid mutators. Genome Biology 9(6):229. https://doi. org/10.1186/gb-2008-9-6-229

Davidson, N. O., Innerarity T. L., Scott, J., Smith, H., Driscoll, D. M., Teng, B., and Chan, L. 1995. Proposed nomenclature for the catalytic subunit of the mammalian apolipoprotein B mRNA editing enzyme: APOBEC-1. RNA 1(1):3.

Di Noia, J. M. and Neuberger, M.S. 2004. Immunoglobulin gene conversion in chicken DT40 cells largely proceeds through an abasic site intermediate generated by excision of the uracil produced by AID-mediated deoxycytidine deamination. European Journal of Immunology 34(2):504-508. https://doi.org/10.1002/eji.200324631

Di Noia, J. M. and Neuberger, M. S. 2007. Molecular mechanisms of antibody somatic hypermutation. Annual Review of Biochemistry 76(1):1-22. https://doi.org/10.1146/ annurev.biochem.76.061705.090740

Doehle, B. P., Schafer, A., and Cullen, B. R. 2005. Human APO$B E C 3 B$ is a potent inhibitor of HIV-1 infectivity and is resistant to HIV-1 Vif. Virology 339(2):281-8. https://doi. org/10.1016/j.virol.2005.06.005

Fu, Y., Ito, F., Zhang, G., Fernandez, B., Yang, H., and Chen, X. S. 2015. DNA cytosine and methylcytosine deamination by APOBEC3B: enhancing methylcytosine deamination by engineering APOBEC3B. Biochemical Journal 471(Pt 1):25-35. https://doi.org/10.1042/BJ20150382

Gaidano, G., Carbone, A., Pastore, C., Capello, D., Migliazza, A., Gloghini, A., Roncella, S., Ferrarini, M., Saglio, G., and Dalla-Favera, R. 1997. Frequent mutation of the 5 ' noncoding region of the $\mathrm{BCL}-6$ gene in acquired immunodeficiency syndrome-related non-Hodgkin's lymphomas. Blood 89(10):3755-62.

Gansmo, L., Romundstad, P., Hveem K., Vatten, L., Nik-Zainal, S., Lønning, P. E., and Knappskog, S. 2018. APOBEC3A/B deletion polymorphism and cancer risk. Carcinogenesis 39(2):118-12. https://doi.org/10.1093/carcin/bgx131

Glaser, A. P., Fantini, D., Wang, Y., Yu, Y., Rimar, K. J., Podojil, J. R., Miller, S. D., and Meeks, J. J. 2018. APOBEC-mediated mutagenesis in urothelial carcinoma is associated with improved survival, mutations in DNA damage response genes, and immune response. Oncotarget 9(4):4537-4548. https://doi.org/10.1101/123802

Göhler, S., Da Silva Filho, M. I., Johansson, R., Enquist-Olsson, K., Henriksson, R., Hemminki, K., Lenner, P, and Försti, A. 2016. Impact of functional germline variants and a deletion polymorphism in APOBEC3A and APO$\mathrm{BEC} B \mathrm{~B}$ on breast cancer risk and survival in a Swedish 
study population. Journal of Cancer Research and Clinical Oncology 142(1):273-276. https://doi.org/10.1007/ s00432-015-2038-7

Goila-Gaur, R., Khan, M. A., Miyagi, E., Kao, S., and Strebel, K. 2007. Targeting APOBEC3A to the viral nucleoprotein complex confers antiviral activity. Retrovirology 4:61. https://doi.org/10.1186/1742-4690-4-61

Green, A. M., Landry, S., Budagyan, K., Avgousti, D. C., Shalhout, S., Bhagwat, A. S., and Weitzman, M. D. 2016. APOBEC3A damages the cellular genome during DNA replication. Cell Cycle 15(7):998-1008. https://doi.org/10.1080 /15384101.2016.1152426

Hanahan, D. and Weinberg, R. A. 2011. Hallmarks of cancer: the next generation. Cell 144(5):646-74. https://doi. org/10.1016/j.cell.2011.02.013

Harris, R. S., Bishop, K. N., Sheehy, A. M., Craig, H. M., Petersen-Mahrt, S. K., Watt, I. N., Neuberger, M.S., and Malim, M. H. 2003. DNA Deamination mediates innate immunity to retroviral infection. Cell 113(6):803-809. https://doi.org/10.1016/S0092-8674(03)00423-9

Harris, R., Petersen-Mahrt, S., and Neuberger, M. 2002. RNA editing enzyme APOBEC 1 and some of its homologs can act as DNA mutators. Molecular Cell 10(5):1247-1253. https://doi.org/10.1016/S1097-2765(02)00742-6

Hoopes, J., Cortez, L., Mertz, T., Malc, E. P., Mieczkowski, P. A., and Roberts, S. A. 2016. APOBEC3A and APOBEC3B preferentially deaminate the lagging strand template during DNA replication. Cell Reports 14(6):1273-1282. https:// doi.org/10.1016/j.celrep.2016.01.021

Hoopes, J.l., Hughes, A. L., Hobson, L. A., Cortez, L. M., Brown, A. J., and Roberts, S. A. 2017. Avoidance of APOBEC3B-induced mutation by error-free lesion bypass. Nucleic Acids Research 45(9):5243-5254. https://doi. org/10.1093/nar/gkx169

Jackson, S. P. and Bartek, J. 2009. The DNA-damage response in human biology and disease. Nature 461(7267):10711078. https://doi.org/10.1038/nature08467

Jarmuz, A., Chester, A., Bayliss, J., Gisbourne, J., Dunham, I., Scott, J., and Navaratnam, N. 2002. An anthropoid-specific locus of orphan $C$ to $U$ RNA editing enzymes on chromosome 22. Genomics 79(3):285-296. https://doi. org/10.1006/geno.2002.6718

Jarvis, M. S., Ebrahimi, D., Temiz, N. A., and Harris, R. S. 2018. Mutation signatures including APOBEC in cancer cell lines. JNCl Cancer Spectrum 2(1):pky002. https://doi. org/10.1093/jncics/pky002

Jha, P., Sinha, S., Kanchan, K., Qidwai, T., Narang, A., et al. 2012. Deletion of the APOBEC3B gene strongly impacts susceptibility to falciparum malaria. Infections, Genetics and Evolution 12(1):142-148. https://doi.org/10.1016/j. meegid.2011.11.001

Kanu, N., Cerone, M. A., Goh, G., Zalmas, L. P., Bartkova, J., Dietzen, M., et al. 2016. DNA replication stress mediates APOBEC3 family mutagenesis in breast cancer. Genome Biology 17(1):185. https://doi.org/10.1186/s13059-0161042-9

Kazanov, M. D., Roberts, S. A., Polak, P., Stamatoyannopoulos, J., Klimczak, L. J., Gordenin, D. A., and Sunyaev, S. R. 2015. APOBEC-induced cancer mutations are uniquely enriched in early-replicating, gene-dense, and active chromatin regions. Cell Reports 13(6):1103-1109. https:// doi.org/10.1016/j.celrep.2015.09.077

Kidd, J., Newman, T. L., Tuzun, E., Kaul, R., and Eichler, E. E. 2007. Population stratification of a common APOBEC gene deletion polymorphism. PLoS Genetics 3(4):e63. https://doi.org/10.1371/journal.pgen.0030063

Kinomoto, M., Kanno, T., Shimura, M., Ishizaka, Y., Kojima, A., Kurata, T., Sata, T., and Tokunaga, K. 2007. All APO-
BEC3 family proteins differentially inhibit LINE-1 retrotransposition. Nucleic Acids Research 35(9):2955-2964. https://doi.org/10.1093/nar/gkm181

Krishnan, A., Iyer, L. M., Holland, S. J., Boehm, T., and Aravind, L. 2018. Diversification of AID/APOBEC-like deaminases in metazoa: multiplicity of clades and widespread roles in immunity. Proceedings of the National Academy of Sciences of the USA 115(14):E3201-E3210. https://doi. org/10.1073/pnas.1720897115

Kumar, R., DiMenna, L. J., Chaudhuri, J., and Evans, T. 2014. Biological function of activation-induced cytidine deaminase (AID). Biomed Journal 37(5):269-83. https://doi. org/10.4103/2319-4170.128734

Lackey, L., Demorest, Z. L., Land, A. M., Hultquist, J.F., Brown, W. L., and Harris, R. S. 2012. APOBEC3B and AID have similar nuclear import mechanisms. Journal of Molecular Biology 419(5):301-314. https://doi.org/10.1016/j. jmb.2012.03.011

Lada, A.G., Dhar, A., Boissy, R, Hirano, M., Rubel, A.A., Rogozin, I. B., and Pavlov, Y.I. 2012. AID/APOBEC cytosine deaminase induces genome-wide kataegis. Biology Direct 7:47. https://doi.org/10.1186/1745-6150-7-47

Lada, A. G., Frahm Krick, C., Kozmin, S. G., Mayorov, V.I., Karpova, T.S., Rogozin, I. B., and Pavlov, Y.I. 2011 a. Mutator effects and mutation signatures of editing deaminases produced in bacteria and yeast. Biochemistry (Moscow) 76(1):131-146. https://doi.org/10.1134/ S0006297911010135

Lada, A. G., Iyer, L. M., Rogozin, I. B., Aravind, L., and Pavlov, Y. I. 2007. Incarnation of classical pro- and eukaryotic mechanisms of mutagenesis in hypermutagenesis and immunity of vertebrates. Russian Journal of Genetics 43(10):1093-1107. https://doi.org/10.1134/ S1022795407100031

Lada, A. G., Kliver, S. F., Dhar, A., Polev, D. E., Masharsky, A. E., Rogozin, I. B., and Pavlov, Y. I. 2015. Disruption of transcriptional coactivator Sub1 leads to genome-wide redistribution of clustered mutations induced by APOBEC in active yeast genes. PLoS Genetics 11(5):e1005217ss. https://doi.org/10.1371/journal.pgen.1005217

Lada, A. G., Stepchenkova, E. I, Waisertreiger, I. S., Noskov, V. N., Dhar, A., Eudy, J. D., Boissy, R. J., Hirano M., Rogozin, I. B., and Pavlov, Y.I. 2013. Genome-wide mutation avalanches induced in diploid yeast cells by a base analog or an APOBEC deaminase. PLoS Genetics 9(9):e1003736. https://doi.org/10.1371/journal. pgen. 1003736

Lada, A. G., Waisertreiger, I.S., Grabow, C. E., Prakash, A., Borgstahl, G. E., Rogozin, I. B., and Pavlov, Y.I. $2011 \mathrm{~b}$. Replication protein A (RPA) hampers the processive action of APOBEC3G cytosine deaminase on single-stranded DNA. PLoS One 6(9):e24848. https://doi.org/10.1371/ journal.pone.0024848

Land, A. M., Law, E. K., Carpenter, M. A., Lackey, L., Brown, W. L., and Harris, R. S. 2013. Endogenous APOBEC3A DNA cytosine deaminase is cytoplasmic and nongenotoxic. Journal of Biological Chemistry 288(24):17253-17260. https:// doi.org/10.1074/jbc.M113.458661

Landry, S., Narvaiza, I., Linfesty, D. C., and Weitzman, M. D. 2011. APOBEC3A can activate the DNA damage response and cause cell-cycle arrest. EMBO Reports 12(5):444-450. https://doi.org/10.1038/embor.2011.46

Law, E. K., Sieuwerts, A. M., LaPara, K., Leonard, B., Starrett, G. J., Molan, A. M., Temiz, N. A., Vogel, R. I., Meijervan Gelder, M.E., Sweep, F. C., et al. 2016. The DNA cytosine deaminase APOBEC3B promotes tamoxifen resistance in ER-positive breast cancer. Science Advances 2(10):e1601737. https://doi.org/10.1126/sciadv.1601737 
Li, J., Zhao, X., Gilbert, E. R., Li, D., Liu, Y., Wang, Y., Zhu, Q., Wang, Y., Chen, Y., and Tian, K. 2014. APOBEC2 mRNA and protein is predominantly expressed in skeletal and cardiac muscles of chickens. Gene 539(2):263-269. https://doi.org/10.1016/j.gene.2014.01.003

Liao, W., Hong, S., Chan, B., Rudolph, F. B., Clark, S. C., and Chan, L. 1999. APOBEC-2, a cardiac- and skeletal muscle-specific member of the cytidine deaminase supergene family. Biochemical and Biophysical Research Communications 260(2):398-404. https://doi.org/10.1006/ bbrc.1999.0925

Loeb, L. A. 2001. A mutator phenotype in cancer. Cancer Research 61:3230-3239. https://doi.org/10.1007/3-54030683-8_1140

Loeb, L. A., Springgate, C. F., Battula, N. 1974. Errors in DNA replication as a basis of malignant changes. Cancer Research 34(9):2311-2321.

Mak, C. H., Pham, P., Afif, S. A., and Goodman, M. F. 2013. A mathematical model for scanning and catalysis on single-stranded DNA, illustrated with activation-induced deoxycytidine deaminase. Journal of Biological Chemistry 288(41):29786-29795. https://doi.org/10.1074/jbc. M113.506550

Marino, D., Perković, M., Hain, A., Vasudevan, A., Hofmann, H., Hanschmann, K., Mühlebach, M.D., Schumann, G. G., König, R., Cichutek, K., Häussinger, D., and Münk, C. 2016. APOBEC4 enhances the replication of HIV-1. PloS ONE 11(6):e0155422. https://doi.org/10.1371/journal. pone. 0155422

Martincorena, I., Raine, K. M., Gerstung, M., Dawson, K.J., Haase, K., Van Loo, P., Davies, H., Stratton, M. R., and Campbell, P.J. 2017. Universal patterns of selection in cancer and somatic tissues. Cell 171(5):1029-1041. e1021. https://doi.org/10.1016/j.cell.2017.09.042

Martincorena, I., Roshan, A., Gerstung, M., Ellis, P., Van Loo, P., McLaren, S., Wedge, D. C., Fullam, A., Alexandrov, L. B., Tubio, J. M., et al. 2015. Tumor evolution. High burden and pervasive positive selection of somatic mutations in normal human skin. Science 348(6237):880-886. https:// doi.org/10.1126/science.aaa6806

Mayorov, V. I., Rogozin, I. B., Adkison, L. R., Frahm, C., Kunkel, T.A., and Pavlov, Y.I. 2005. Expression of human AID in yeast induces mutations in context similar to the context of somatic hypermutation at G-C pairs in immunoglobulin genes. BMC Immunology 6:10. https://doi. org/10.1186/1471-2172-6-10

Middlebrooks, C. D., Banday, A. R., Matsuda, K., et al. 2016. Association of germline variants in the APOBEC3 region with cancer risk and enrichment with APOBEC signature mutations in tumors. Nature Genetics 48(11):1330-1338. https://doi.org/10.1038/ng.3670

Morisawa, T., Marusawa, H., Ueda, Y., Iwai, A., Okazaki, I., Honjo, T., and Chiba, T. 2008. Organ-specific profiles of genetic changes in cancers caused by activation-induced cytidine deaminase expression. International Journal of Cancer 123(12):2735-2740. https://doi.org/10.1002/ ijc. 23853

Muckenfuss, H., Hamdorf, M., Held, U., Perkovic, M., Löwer, J., Cichutek, K., Flory, E., Schumann, G. G., and Münk, C. 2006. APOBEC3 proteins inhibit human LINE-1 retrotransposition. Journal of Biological Chemistry 281:22161-22172. https://doi.org/10.1074/jbc.M601716200

Muramatsu, M., Kinoshita, K., Fagarasan, S., Yamada, S., Shinkai, Y., and Honjo, T. 2000. Class switch recombination and hypermutation require activation-induced cytidine deaminase (AID), a potential RNA editing enzyme. Cell 102(5):553-563. https://doi.org/10.1016/S0092$8674(00) 00078-7$
Muramatsu, M., Sankaranand, V.S., Anant, S., Sugai, M., Kinoshita, K., Davidson, N. O., and Honjo, T. 1999. Specific expression of activation-induced cytidine deaminase (AID), a novel member of the RNA-editing deaminase family in germinal center B cells. Journal of Biological Chemistry 274:18470-18476. https://doi.org/10.1074/ jbc.274.26.18470

Narvaiza, I., Linfesty, D. C., Greener, B. N., Hakata, Y., Pintel, D. J., Logue, E., Landau, N. R., and Weitzman, M. D. 2009. Deaminase-independent inhibition of parvoviruses by the APOBEC3A cytidine deaminase. PLoS Pathogens 5(5):e1000439. https://doi.org/10.1371/journal.ppat.1000439

Neuberger, M.S., Harris, R.S., Di Noia, J., and PetersenMahrt, S. K. 2003. Immunity through DNA deamination. Trends in Biochemical Sciences 28(6):305-312. https://doi. org/10.1016/S0968-0004(03)00111-7

Nik-Zainal, S., Alexandrov, L., Wedge, D., et al. 2012. Mutational processes molding the genomes of 21 breast cancers. Cell 149(5-10):979-993. https://doi.org/10.1016/j. cell.2012.04.024

Nik-Zainal, S., Davies, H., Staaf, J., Ramakrishna, M., Glodzik, D., Zou, X., et al. 2016. Landscape of somatic mutations in 560 breast cancer whole-genome sequences. Nature 534(7605):47-54. https://doi.org/10.1038/nature17676

Nik-Zainal, S. and Morganella, S. 2017. Mutational signatures in breast cancer: the problem at the DNA level. Clinical Cancer Research 23(11):2617-2629. https://doi. org/10.1158/1078-0432.CCR-16-2810

Nik-Zainal, S., Wedge, D., Alexandrov, L., et al. 2014. Association of a germline copy number polymorphism of APO$B E C 3 A$ and $A P O B E C 3 B$ with burden of putative APOBECdependent mutations in breast cancer. Nature Genetics 46(5):487-491. https://doi.org/10.1038/ng.2955

Nussenzweig, A. and Nussenzweig, M. C. 2010. Origin of chromosomal translocations in lymphoid cancer. Cell 141(1):27-38. https://doi.org/10.1016/j.cell.2010.03.016

Okazaki, I., Hiai, H., Kakazu, N., Yamada, S., Muramatsu, M., Kinoshita, K., and Honjo, T. 2003. Constitutive expression of AID leads to tumorigenesis. Journal of Experimental Medicine 197(9):1173-1181. https://doi.org/10.1084/jem.20030275

Okazaki, I., Kinoshita, K., Muramatsu, M., Yoshikawa, K., and Honjo, T. 2002. The AID enzyme induces class switch recombination in fibroblasts. Nature 416(6878):340-345. https://doi.org/10.1038/nature727

Okazaki, I., Kotani, A., and Honjo, T. 2007. Role of AID in tumorigenesis. Advances in Immunology 94:245-273. https://doi.org/10.1016/S0065-2776(06)94008-5

Okuyama, S., Marusawa, H., Matsumoto, T., Ueda, Y., Matsumoto, Y., Endo, Y., Takai, A., and Chiba, T. 2011. Excessive activity of apolipoprotein B mRNA editing enzyme catalytic polypeptide 2 (APOBEC2) contributes to liver and lung tumorigenesis. International Journal of Cancer 130(6):1294-1301. https://doi.org/10.1002/ijc.26114

Orecchini, E., Frassinelli, L., Galardi, S., Ciafrè, S. A., and Michienzi, A. 2018. Post-transcriptional regulation of LINE-1 retrotransposition by AID/APOBEC and ADAR deaminases. Chromosome Research 25(1-2):45-59. https://doi. org/10.1007/s10577-018-9572-5

Papavasiliou, F. N. and Schatz, D. G. 2002. Somatic hypermutation of immunoglobulin genes: merging mechanisms for genetic diversity. Cell 109(2):S35-S44. https://doi. org/10.1016/S0092-8674(02)00706-7

Pasqualucci, L., Neumeister, P., Goossens, T., Nanjangud, G., Chaganti, R. S. K., Kuppers, R., and Dalla-Favera, R. 2001. Hypermutation of multiple proto-oncogenes in B-cell diffuse large-cell lymphomas. Nature 412(6844):341346. https://doi.org/10.1038/35085588 
Pak, V., Heidecker, G., Pathak, V. K., and Derse, D. 2011. The role of amino-terminal sequences in cellular localization and antiviral activity of APOBEC3B. Journal of Virology 85(17):8538-8547. https://doi.org/10.1128/JVI. 02645-10

Periyasamy, M., Patel, H., Lai, C., et al. 2015. APOBEC3B-mediated cytidine deamination is required for estrogen receptor action in breast cancer. Cell Reports 13(1):108121. https://doi.org/10.1016/j.celrep.2015.08.066

Petersen-Mahrt, S. K., Harris, R. S., and Neuberger, M. S. 2002. AID mutates $E$. coli suggesting a DNA deamination mechanism for antibody diversification. Nature 418(6893):99104. https://doi.org/10.1038/nature00862

Pham, P., Bransteitter, R., Petruska, J., and Goodman, M. F. 2003. Processive AID-catalysed cytosine deamination on single-stranded DNA simulates somatic hypermutation. Nature 424(6944):103-107. https://doi.org/10.1038/nature 01760

Pham, P., Smolka, M. B., Calabrese, P., Landolph, A., Zhang, K., Zhou, H., and Goodman, M. F. 2008. Impact of phosphorylation and phosphorylation-null mutants on the activity and deamination specificity of activation-induced cytidine deaminase. The Journal of Biological Chemistry 283(25):17428-17439. https://doi.org/10.1074/jbc. M802121200

Poltoratsky, V., Heacock, M., Kissling, G. E., Prasad, R., and Wilson, S.H. 2010. Mutagenesis dependent upon the combination of activation-induced deaminase expression and a double-strand break. Molecular Immunology 48(1-3):164-170. https://doi.org/10.1016/j.molimm.2010.08.013

Poltoratsky, V. P., Wilson, S. H., Kunkel, T. A., and Pavlov, Y. I. 2004. Recombinogenic phenotype of human activationinduced cytosine deaminase. The Journal of Immunology 172(7):4308-4313. https://doi.org/10.4049/jimmunol.172.7.4308

Powell, L. M., Wallis, S. C., Pease, R. J., Edwards, Y. H., Knott, T. J., and Scott, J. 1987. A novel form of tissue-specific RNA processing produces apolipoprotein-B48 in intestine. Cell 50(6):831-840. https://doi.org/10.1016/00928674(87)90510-1

Qian, J., Wang, Q, Dose, M., Pruett, N., Kieffer-Kwon, K., Resch, W., Liang, G., Tang, Z., Mathé, E., Benner, C., Dubois, W., Nelson, S., Vian, L., Oliveira, T. Y., Jankovic, M., Hakim, O., Gazumyan, A., Pavri, R., Awasthi, P., Song, B., Liu, G., Chen, L., Zhu, S., Feigenbaum, L., Staudt, L., Murre, C., Ruan, Y., Robbiani, D. F., Pan-Hammarström, Q., Nussenzweig, M. C., and Casellas, R. 2014. B Cell super-enhancers and regulatory clusters recruit AID tumorigenic activity. Cell 159(7):15241537. https://doi.org/10.1016/j.cell.2014.11.013

Ramiro, A.R., Jankovic, M., Eisenreich, T., Difilippantonio, S., Chen-Kiang, S., Muramatsu, M., Honjo, T., Nussenzweig, A., and Nussenzweig, M. C. 2004. AID is required for c-myc/lgH chromosome translocations in vivo. Cell 118(4):431-438. https://doi.org/10.1016/j. cell.2004.08.006

Revy, P., Muto, T., Levy, Y., Geissmann, F., Plebani, A., Sanal, O., Catalan, N., Forveille, M., Dufourcq-Labelouse, R., Gennery, A., Tezcan, I., Ersoy, F., Kayserili, H., Ugazio, A. G., Brousse, N., Muramatsu, M., Notarangelo, L. D., Kinoshita, K., Honjo, T., Fischer, A., and Durandy, A. 2000. Activation-induced cytidine deaminase (AID) deficiency causes the autosomal recessive form of the Hyper-IgM syndrome (HIGM2). Cell 102(5):565-575. https://doi.org/10.1016/S0092-8674(00)00079-9

Robbiani, D., Bunting, S., Feldhahn, N., Bothmer, A., Camps, J., Deroubaix, S., McBride, K.M., Klein, I. A., Stone, G., Eisenreich, T.R., Ried, T., Nussenzweig, A., and Nussenzweig, M. C. 2009. AID produces DNA double-strand breaks in non-lg genes and mature B cell lymphomas with reciprocal chromosome translocations. Molecular Cell 36(4):631-641. https://doi.org/10.1016/j.molcel.2009.11.007

Roberts, S. A. and Gordenin, D. A. 2014. Hypermutation in human cancer genomes: footprints and mechanisms. Nature Reviews Cancer 14(12):786-800. https://doi. org/10.1038/nrc3816

Roberts, S, Lawrence, M. S., Klimczak, L. J., Grimm, S. A., Fargo, D., Petar Stojanov, P., Kiezun, A., Kryukov, G. V., Carter, S. L., Saksena, G., Harris, S., Shah, R. R., Resnick, M.A., Getz, G., and Gordenin, D. A. 2013. An APOBEC cytidine deaminase mutagenesis pattern is widespread in human cancers. $\mathrm{Na}$ ture Genetics 45(9):970-976. https://doi.org/10.1038/ng.2702

Roberts, S., Sterling, J., Thompson, C., Harris, S., Mav, D., Shah, R., Klimczak, L.J., Kryukov, G. V., Malc, E., Mieczkowski, P. A., Resnick, M. A., and Gordenin, D. A. 2012. Clustered mutations in yeast and in human cancers can arise from damaged long single-strand DNA regions. Molecular Cell 46(4):424-435. https://doi.org/10.1016/j. molcel.2012.03.030

Rogozin, I. B., Babenko, V. N., Milanesi, L., and Pavlov, Y.I. 2003. Computational analysis of mutation spectra. Briefings Bioinformatics 4(3):210-227. https://doi. org/10.1093/bib/4.3.210

Rogozin, I. B., Basu, M. K., Jordan, I. K, Pavlov, Y. I., and Koonin, E.V. 2005. APOBEC4, a new member of the AID/ APOBEC family of polynucleotide (deoxy) cytidine deaminases predicted by computational analysis. Cell cycle 4(9):1281-1285. https://doi.org/10.4161/cc.4.9.1994

Rogozin, I. B., Iyer, L. M., Liang, L., Glazko, G. V., Liston, V. G., Pavlov, Y. I., Aravind, L., and Pancer, Z. 2007. Evolution and diversification of lamprey antigen receptors: evidence for involvement of an AID-APOBEC family cytosine deaminase. Nature Immunology 8(6):647-656. https:// doi.org/10.1038/ni1463

Rogozin, I. B. and Pavlov, Y.I. 2003. Theoretical analysis of mutation hotspots and their DNA sequence context specificity. Mutation Research 544(1):65-85. https://doi. org/10.1016/S1383-5742(03)00032-2

Rogozin, I. B. and Pavlov, Y. I. 2006. The cytidine deaminase AID exhibits similar functional properties in yeast and mammals. Molecular Immunology 43(9):1481-1484. https://doi.org/10.1016/j.molimm.2005.09.002

Rogozin, I. B., Pavlov, Y. I., Goncearenco, A., De, S., Lada, A. G., Poliakov, E., Panchenko, A. R., and Cooper, D. N. 2018. Mutational signatures and mutable motifs in cancer genomes. Briefings Bioinformatics 19(6):1-17. https://doi. org/10.1093/bib/bbx049

Rogozin, I. B., Roche-Lima, A., Lada, A. G., Belinky, F., Sidorenko, I. A., Glazko, G. V., Babenko, V. N., Cooper, D. N., and Pavlov, Y. I. 2019. Nucleotide weight matrices reveal ubiquitous mutational footprints of AID/APOBEC deaminases in human cancer genomes. Cancers 11(2):211. https://doi.org/10.3390/cancers11020211

Rosenberg, B. R, Hamilton, C. E., Mwangi, M. M., Dewell, S, and Papavasiliou, F. N. 2011. Transcriptome-wide sequencing reveals numerous APOBEC 1 mRNA editing targets in transcript 3' UTRs. Nature Structural \& Molecular Biology 18(2):230-236. https://doi.org/10.1038/nsmb.1975

Saini, N., Roberts, S. A., Sterling, J. F., Malc, E. P., Mieczkowski, P.A., and Gordenin, D. A. 2017. APOBEC3B cytidine deaminase targets the non-transcribed strand of tRNA genes in yeast. DNA Repair 53:4-14. https://doi. org/10.1016/j.dnarep.2017.03.003

Sakofsky, C. J., Roberts, S. A., Malc, E., Mieczkowski, P. A., Resnick, M. A., Gordenin, D. A., and Malkova, A. 2014. Breakinduced replication is a source of mutation clusters un- 
derlying kataegis. Cell Reports 7(5):1640-1648. https:// doi.org/10.1016/j.celrep.2014.04.053

Salter, J. D., Bennett, R. P., and Smith, H. C. 2016. The APOBEC protein family: united by structure, divergent in function. Trends in Biochemical Sciences 41(7):578-594. https://doi. org/10.1016/j.tibs.2016.05.001

Samaranayake, M., Bujnicki, J. M., Carpenter, M., and Bhagwat, A.S. 2006. Evaluation of molecular models for the affinity maturation of antibodies: roles of cytosine deamination by AID and DNA repair. Chemical Reviews 106(2):700-719. https://doi.org/10.1021/cr040496t

Sato, Y., Ohtsubo, H., Naohiro Nihei, N., Kaneko, T., Sato, Y., Adachi, S., Kondo, S., Nakamura, M., Mizunoya, W., lida, H., Tatsumi, R., Rada, C., and Yoshizawa, F. 2017. Apobec2 deficiency causes mitochondrial defects and mitophagy in skeletal muscle. The FASEB Journal 32(3):fj.201700493R. https://doi.org/10.1096/ fj.201700493R

Sato, Y., Probst, H. C., Tatsumi, R., Ikeuchi, Y., Neuberger, M. S., and Rada, C. 2009. Deficiency in APOBEC2 leads to a shift in muscle fiber type, diminished body mass, and myopathy. Journal of Biological Chemistry 285(10):7111-7118. https://doi.org/10.1074/jbc.M109.052977

Schumacher, A.J., Nissley, D. V., and Harris, R. S. 2005. APOBEC3G hypermutates genomic DNA and inhibits Ty1 retrotransposition in yeast. Proceedings of the National Academy of Sciences of the USA 102(28):9854-9859. https:// doi.org/10.1073/pnas.0501694102

Schumann, G. G. 2007. APOBEC3 proteins: major players in intracellular defence against LINE-1-mediated retrotransposition. Biochemical Society Transactions 35(Pt 3):637-642. https://doi.org/10.1042/BST0350637

Seplyarskiy, V. B., Soldatov, R. A., Popadin, K.Y., Antonarakis, S. E., Bazykin, G. A., and Nikolaev, S. I. 2016. APOBECinduced mutations in human cancers are strongly enriched on the lagging DNA strand during replication. Genome Research 26(2):174-182. https://doi.org/10.1101/ gr.197046.115

Sharma, S., Patnaik, S. K., Taggart, R. T., Kannisto, E. D., Enriquez, S. M., Gollnick, P., and Baysal, B. E. 2015. APOBEC3A cytidine deaminase induces RNA editing in monocytes and macrophages. Nature Communications 6:6881. https://doi.org/10.1038/ncomms7881

Sharma, S., Patnaik, S. K., Kemer, Z., and Baysal, B. E. 2017. Transient overexpression of exogenous APOBEC3A causes C-to-U RNA editing of thousands of genes. RNA Biology 14(5):603-610. https://doi.org/10.1080/1547628 6.2016 .1184387

Sheehy, A. M., Gaddis, N.C., Choi, J.D., and Malim, M. H. 2002. Isolation of a human gene that inhibits HIV-1 infection and is suppressed by the viral Vif protein. $\mathrm{Na}$ ture 418(6898):646-650. https://doi.org/10.1038/nature00939

Shiloh, Y. 2003. ATM and related protein kinases: safeguarding genome integrity. Nature Reviews Cancer 3(3):155168. https://doi.org/10.1038/nrc1011

Siriwardena, S. U., Perera, M. L.W., Senevirathne, V., Stewart, J., and Bhagwat, A.S. 2018. A tumor-promoting phorbol ester causes a large increase in APOBEC3A expression and a moderate increase in APOBEC3B expression in a normal human keratinocyte cell line without increasing genomic uracils. Molecular and Cellular Biology 39(1):e00238-18. https://doi.org/10.1128/MCB.00238-18

Stenglein, M. D. and Harris R. S. 2006. APOBEC3B and APOBEC3F Inhibit L1 Retrotransposition by a DNA Deamination-independent Mechanism. Journal of Biological Chemistry 281:16837-16841. https://doi.org/10.1074/ jbc.M602367200
Stavnezer, J. and Schrader, C. E. 2006. Mismatch repair converts AID-instigated nicks to double-strand breaks for antibody class-switch recombination. Trends in Genetics 22(1):23-28. https://doi.org/10.1016/j.tig.2005.11.002

Stratton, M. R., Campbell, P.J., and Futreal, P. A. 2009. The cancer genome. Nature 458(7239):719-724. https://doi. org/10.1038/nature07943

Suspene, R., Aynauda, M-M., Guétard, D., Henry, M., Eckhoff, G., Marchio, A., Pineau, Dejean, A., Vartanian, J-P., and Wain-Hobson, S. 2011. Somatic hypermutation of human mitochondrial and nuclear DNA by APOBEC3 cytidine deaminases, a pathway for DNA catabolism. Proceedings of the National Academy of Sciences of the USA 108(12):4858-4863. https://doi.org/10.1073/ pnas.1009687108

Suspene, R., Guétard, D., Henry, M., Sommer, P., Wain-Hobson, S., and Vartanian, J-P. 2005. Extensive editing of both hepatitis B virus DNA strands by APOBEC3 cytidine deaminases in vitro and in vivo. Proceedings of the $\mathrm{Na}$ tional Academy of Sciences of the USA 102(23):8321-8326. https://doi.org/10.1073/pnas.0408223102

Suspene, R., Mussil, B., Laude, H., Caval, V., Berry, N., Bouzidi, M. S., Thiers, V., Wain-Hobson, S., and Vartanian, J. 2017. Self-cytoplasmic DNA upregulates the mutator enzyme APOBEC3A leading to chromosomal DNA damage. Nucleic Acids Research 45(6):3231-3241. https://doi. org/10.1093/nar/gkx001

Taylor, B., Nik-Zainal, S., Wu, Y. L., Stebbings, L. A., Raine, K., Campbell, P.J., Rada, C., Stratton, M. R., and Neuberger, M. S. 2013. DNA deaminases induce break-associated mutation showers with implication of APOBEC3B and 3A in breast cancer kataegis. eLife 2:e00534. https://doi. org/10.7554/eLife.00534

Taylor, B.J., Wu, Y. L., and Rada, C. 2014. Active RNAP preinitiation sites are highly mutated by cytidine deaminases in yeast, with AID targeting small RNA genes. eLife 3:e03553. https://doi.org/10.7554/eLife.03553

Teng, B., Burant, S., and Davidson, N. 1993. Molecular cloning of an apolipoprotein B messenger RNA editing protein. Science 260(5115):1816-1819. https://doi.org/10.1126/ science. 8511591

Vartanian, J. P., Guétard, D., Henry, M., and Wain-Hobson, S. 2008. Evidence for editing of human papillomavirus DNA by APOBEC3 in benign and precancerous lesions. Science 320(5873):230-233. https://doi.org/10.1126/science. 1153201

Walker, B., Wardell, C.P., Murison, A., et al. 2015. APOBEC family mutational signatures are associated with poor prognosis translocations in multiple myeloma. Nature Communications 6:6997. https://doi.org/10.1038/ncomms7997

Xiao, X., Yang, H., Arutiunian, V., Fang, Y., Besse, G., Morimoto, C., Zirkle, B., and Chen, X. S. 2017. Structural determinants of APOBEC3B non-catalytic domain for molecular assembly and catalytic regulation. Nucleic Acids Research 45(12):7494-7506. https://doi.org/10.1093/ nar/gkx362

Xuan, D., Li, G., Cai, Q., et al. 2013. APOBEC3 deletion polymorphism is associated with breast cancer risk among women of European ancestry. Carcinogenesis 34(10):22402243. https://doi.org/10.1093/carcin/bgt185

Yamanaka, S., Balestra, M. E., Ferrell, L. D., Fan, J., Arnold, K. S., Taylor, S., Taylor, J. M., and Innerarity, T. L. 1995. Apolipoprotein B mRNA-editing protein induces hepatocellular carcinoma and dysplasia in transgenic animals. Proceedings of the National Academy of Sciences of the USA 92(18):8483-8487. https://doi.org/10.1073/ pnas.92.18.8483 
Yoshikawa, K., Okazaki, I. M., Eto, T., Kinoshita, K., Muramatsu, M., Nagaoka, H., and Honjo, T. 2002. AID enzymeinduced hypermutation in an actively transcribed gene in fibroblasts. Science 296(5575):2033-2036. https://doi. org/10.1126/science.1071556

Yu, Q., Chen, D., König, R., Mariani, R., Unutmaz, D., and Landau, N. R. 2004. APOBEC3B and APOBEC3C are potent inhibitors of simian immunodeficiency virus replication. Journal of Biological Chemistry 279:53379-53386. https:// doi.org/10.1074/jbc.M408802200
Zan, H. and Casali, P. 2013. Regulation of Aicda expression and AID activity. Autoimmunity 46(2):83-101. https://doi. org/10.3109/08916934.2012.749244

Zhang, T., Cai, J., Chang, J., Yu, D., Wu, C., Yan, T., Zhai, K., Bi, X., Zhao, H., Xu, J., Tan, W., Qu, C., Lin, D. 2013. Evidence of associations of APOBEC3B gene deletion with susceptibility to persistent HBV infection and hepatocellular carcinoma. Human Molecular Genetics 22(6):1262-1269. https://doi.org/10.1093/hmg/dds513 